\title{
GOVERNANCE IN PTOLEMAIC EGYPT, THE FIRST HUNDRED YEARS: A CASE OF IMPERIALISM?*
}

\author{
J Adler (University of Stellenbosch)
}

\begin{abstract}
This article investigates the nature of governance in Ptolemaic Egypt during the first 100 years of their rule. It proposes that this governance was Imperialist and exploitative in nature and that the Macedonian Greeks acted as the master race while their Egyptian subjects were either collaborators in this exploitation (a small minority of no more than $2.5 \%$ ) or the exploited.
\end{abstract}

In order to substantiate this submission, the nature of concepts such as imperialism, colonialism and colonization are defined and explored. Where applicable, comparisons are made with modern empires. The institutions of empire and the racist nature of Ptolemaic rule are investigated while the economic measures instituted to ensure maximum profit for the imperialists, are also examined.

\section{Introduction}

The objective of this paper is to make an assessment of the form and style of government during the first 100 years of Ptolemaic rule in Egypt.

In Ptolemaic Egypt (323 BC-31 BC), the rulers and the ruling class (particularly the expatriate intellectual elite) regarded themselves essentially as Greco-Macedonian conquerors. Because of the fact that these expatriates ruled Egypt, the nature of Ptolemaic Egyptian rule, in my view, was imperialistic at the outset and for approximately the first 100 years of its existence. In addition, the Ptolemaic rulers inherited and vastly expanded foreign territories external to the boundaries of Egypt.

\section{Imperialism and Colonialism - the antecedents}

Colonization was not a foreign concept to the Greeks. From their earliest history, they were forced to look beyond their borders for Lebensraum. Even in antiquity, the Greek mainland and most of the islands were barren and dry. The country was never able to carry any growth in its population and, from as early as the eight century BC, the Greeks started to establish colonies to accommodate their surplus population. This export of people is an abiding Greek phenomenon that has continued, in different forms, up to the present. Colonies were soon established on the north Syrian coast, in Italy and on the south coast of the Black Sea.

The Greek mother cities of antiquity were, however, not interested in ruling their colonies. A soon as possible, these newly established states became independent political entities, "normally keeping no more than sentimental and religious ties with [their] mother city" (Forest 2001:17). This process cannot be described as colonialism or imperialism but rather as "colonization", the term suggested for this process by Lüthy. He believes colonization has been, from the beginning of history, a tremendous process by which the world was discovered, opened to man, and settled; the process by which roads, coasts and oceans were made accessible and safe, by which closed continents, forbidden kingdoms and isolated

* This article is based on a MPhil study completed at Stellenbosch University in December 2004. 
societies were forced open or broken up by the new expanding forces, new techniques, new customs, new knowledge, and new forms of social organization. The word colonization, indeed, means nothing but the spreading of culture . . . (Lüthy 1964:29).

\section{Defining imperialism and colonialism}

Imperialism and colonialism are different animals altogether from colonization. These two concepts are based on assumptions about the superiority of the conquering nation and the inferiority of the conquered. Cartledge (1993:40) points out that, from the earliest times, the Greeks divided humankind into two mutually exclusive categories: Greeks and Barbarians, Us and Them. He argues that the Greeks regarded themselves as "naturally" free and barbarians as "naturally" servile, and that Aristotle paved the way for imperialistic thinking by suggesting that, if the Hellenic people could bridge their differences and form a united front, they would be able to rule the world. This, of course, is exactly what Phillip II and Alexander of Macedon achieved and this way of thinking was "an open invitation to ... cultural imperialism by the Greeks” (Cartledge 1993:40).

There is a great deal of confusion and disagreement among scholars as to the meaning of the two terms imperialism and colonialism, but they overlap, inter alia in the sense that both have connotations of exploitation and oppression. What seems to emerge is that, although empires were functioning realities in antiquity, the terms imperialism and colonialism have obtained an emotionally charged meaning in the post-colonial/postmodern era. Scholtz maintains that imperialism is the more embracing of the two: "You can have a colony without an empire, but you cannot have an empire without colonies” (Scholtz 2003:interview). Colonization, on the other hand, is an emotionally neutral concept used in the sense of occupying new, often vacant, territory.

Cook defines imperialism as "the practice by a country, which has become a nation and embarked upon commercial and industrial expansion, of acquiring and administering territories, inhabited by people usually at a lower stage of development, as colonies or dependencies" (1981:28). This is done for the benefit of the conqueror. Lipset $(1995: 262)$ holds that this system, in which countries maintain colonies, invariably results in an undemocratic form of government.

Bullock (1999:418) defines imperialism as "the extension of the power of a state through the acquisition, usually by conquest, of other territories; the subjugation of their inhabitants to an alien rule imposed on them by force, and their economic and financial exploitation by the imperial power. Imperialism in this general sense of 'empire' is as old as history". Nadel (1964:2) agrees and concludes that the term imperialism is "a word whose history is very much shorter than that of the phenomena which it describes".

Ferguson defines empire as "the extension of one's civilization, usually by military force, to rule over other peoples” (2004:169). Woolf (2001:311) suggests that ancient empires normally displayed certain characteristics. Elites whose power was limited by low levels of surplus production and pre-industrial communications and technology ruled most ancient empires. Imperial aristocracies thus depended on devolving a great part of their running costs on local elites.

Ancient empires were therefore of necessity tolerant of regional diversity and their rulers set themselves modest goals, often little more than maintaining their security against internal and external threats and extracting sufficient profit to reward those on whom imperial power 
depended. Despite, or perhaps because of, the resultant lack of homogeneity, many ancient empires were very long lasting (Woolf 2001:311).

Bullock describes colonialism, on the other hand, as "a form of imperialism based on maintaining a sharp and fundamental distinction (expressed often in law as well as fact) between the ruling nation and the subordinate (colonial) populations” (1999:418). He argues that such arrangements develop most naturally because of the conquest of a territory with a population of a conspicuously different physique and/or culture (1999:418). This is of course not always the case, but what is certain is that colonialism always entails unequal rights.

It would seem that in the case of imperialism, the exploitation and oppression emanate from an external, foreign group or nation. A locally based group, on the other hand, could under certain circumstances, practice colonialist exploitation and oppression, with no ties to a foreign power. In this regard, it is interesting to note that British rule in South Africa has universally been described as imperialist while the rule of the indigenous Afrikaner minority who maintained no connection to Europe, although originating from there, has consistently been described as colonialist in nature.

In an important article entitled "Decolonizing Ptolemaic Egypt”, Bagnall concludes that we can accept that the Hellenistic world was, in essence, colonial in nature. He warns that there are important differences between modern colonial worlds and ancient societies. However, he concludes that “ ... accepting the 'colonial hypothesis' opens up such a large range of useful modern literature that we can renovate our entire approach to Hellenistic society” (1997:227).

Bagnall says that the first important difference between modern and ancient empires is that the conquest of the East by Alexander and his successors was essentially military and political in character and origin, whereas modern colonization was a result of the desire to expand economically. He regards this distinction as an important difference between ancient Greek culture and modern capitalist civilization. He does concede, however, that Alexander's successors, the early Hellenistic kings (including the Ptolemaic kings), did seek to provide the resources for their political aspirations through the systematic economic exploitation of their empires and were therefore equally driven by economic or financial gain.

The second distinction that Bagnall draws is that almost all modern colonialism was accompanied by, and sometimes largely executed by, a missionary religious movement, propagating and universalising monotheistic religion; by contrast, both conquerors and conquered in the Hellenistic world were polytheists, open to the cults of others and not particularly intent on imposing their own on anyone. The efforts of modern classicists to read a missionary purpose into Greek expansion during and after the time of Alexander were clearly influenced by their own colonialist past and are today rejected by nearly all postmodern scholars. Green concludes, "I regard the whole notion of a conscious, idealistic, missionary propagation in conquered territories of Greek culture, mores, literature, art and religion ... a as a pernicious myth, compounded of anachronistic Christian evangelism and Plutarch-inspired wishful thinking, ... to provide moral justification for what was, in essence . . large-scale economic and imperial exploitation” (1990:xv).

The stated objective of most empires throughout history was what we may call a civilizing or proselytising, missionary zeal. In the case of the Romans, for instance, this consisted of a mission to preserve technological improvements introduced by them and to disseminate it throughout the world (Woolf 2001:319). Similarly, the imperialism of $18^{\text {th }}$ and $19^{\text {th }}$ century Europeans was usually justified as the dissemination of Western civilization, religion and 
values to "inferior" peoples. In a review of Nial Ferguson's The Rise and Demise of the British World Order and the Lessons of Global Power, Michico Kakutani notes that some of the positive achievements of the British Empire cited by Ferguson - including the exportation of liberal capitalism and parliamentary democracy - uncannily echo aims articulated by American proponents of the war in Iraq (2003:18).

The Macedonian Greeks never felt the need to justify the occupation of Egypt. Throughout the ages, until the recent past, such explanations were neither expected nor given. The simple reality was that military, economic and geo-political superiority was gained for the Greeks by the exploits of Alexander. Seen through modern eyes, Ptolemaic Alexandria was indeed an imperialistic regime imposed on an unwilling but military inferior Egyptian populace by a Greek diaspora, who pressed their culture, social and economic practices, religious beliefs and way of life upon the conquered nation.

According to Bagnall, modern imperialism and colonialism have also been characterized by systematic racism:

The indigenous populations of the colonized countries were generally viewed not only as inferior and backward - and therefore proper receptacles of the bounty of the western civilizing mission - but as ineradicably inferior, incapable ever of rising to the level of the colonizers. Certainly the Greeks - like other ancient peoples - habitually regarded themselves as superior to others, and even described them at times as slaves by nature. But even so they lacked systematic racism, particularly one based on skin colour, and their attitudes toward "barbarians" were by no means entirely negative (1997:230).

The Graeco-Macedonians saw themselves, nevertheless, as the master race, which, because of its refined culture, ability to wage war and the inherent superiority of the Greek language and heritage, had the right to rule over inferior races. Racism was rampant among the Greeks and Macedonians of Alexandria, and never died out entirely (Green 1990:316). The Egyptians, on the other hand, undoubtedly regarded the Ptolemaic regime as invasive and, from relatively early on, attempted to rid themselves of the burden placed upon them by the foreigners. The fact that the Egyptians regarded their own more ancient civilization as at least as advanced as, and perhaps as superior to, that of the invaders, did not contribute to their acquiescence to Greek rule. On the contrary, their resentment caused continuous rebellion and unrest in the streets of Alexandria and throughout Egypt.

The impact of the resentment to what Chua calls "market-dominant minorities: ethnic minorities who, for varying reasons, tend to dominate economically, often to a startling extent, the indigenous majorities" (2003:3), cannot be overestimated. She explains that "the ... most ferocious kind of backlash is majority-supported violence aimed at eliminating a market-dominating minority” (2003:5). During the second century of Ptolemaic rule, this danger became startlingly apparent. This phenomenon usually contains class as well as racial elements.

The economic stratification and inherent class system under which the vast majority of Egyptians suffered, contributed more to the Egyptians' resistance to Greek rule than any racism they may have encountered. This stratification and the systematic exploitation by the privileged class (largely Greek) of the lower stratum of society (mainly Egyptian) were harsh realities.

The third difference between modern and ancient empires and colonialisms according to Bagnall is that modern colonialism is virtually defined by the existence of a metropolitan 
centre outside the colonized land, to which the wealth extracted from the colony flows and where ultimate power resides. In contrast,

For the Hellenistic kingdoms there was no such metropolitan centre. ... Nor can one avoid the difficulty by claiming that Alexandria was such a metropolitan centre. In reality Egypt's metropolis was tightly woven into the economic and political fabric of the country on whose ground it stood. It cannot be taken for an equivalent to Paris, London or Brussels. The straightforward description of Ptolemaic Egypt as a colony thus encounters some significant structural difficulties (1997:230-231).

Still, during the Ptolemaic period, foreigners ruled in Egypt. If we accept that a typical empire normally operates from a home base (a metropolitan centre) and rules its member states from there for the benefit or profit of the home country, Ptolemaic Egypt presents us with a problem. Although the ruling elite in Ptolemaic Egypt originally came from Macedonia and Greece, Egypt was not ruled from there but from the newly created enclave, Alexandria, which was, after all, still part of Egypt. As Green (1990:192) points out, "[The Ptolemies] were actually resident in the country - in it, yet not of it; insulated by their Greek-speaking court and bureaucracy, largely indifferent to Egyptian culture, exploiters in an alien world”. Contrary to Bagnall's conclusion, Alexandria could therefore justifiably be described as the metropolitan centre of the Egyptian empire.

In considering Bagnall's discussion of modern and ancient colonialism, I believe that focusing on colonialism per se may be less rewarding than thinking about colonialism in conjunction with the larger phenomenon of imperialism and hierarchical systems in general. If one views Egypt under Ptolemaic rule as imperialistic rather than as colonial, the situation becomes much clearer.

Imperialist exploitation by a state is not always profitable in view of the high military and other costs. H N Brailsford, in The War of Steel and Gold, as quoted by Kiernan, states:

Regarded as a national undertaking Imperialism does not pay. Regarded as a means of assuring unearned income to the governing class, it emphatically does pay (Kiernan 1974:5).

It is in this sense that I propose that Ptolemaic Egypt was indeed an imperialist state. The fact that the dominant class was Greek while the exploited class was Egyptian complicated matters.

\section{The imperialist nature of Ptolemaic rule}

Hölbl maintains that Ptolemy I's task of competing with the other Successors and of building up his empire in territories outside Egypt was only one of the two main sets of political problems with which he had to deal.

The second, very heterogeneous set of problems was the question of how he was to proceed within Egypt. ... a modus vivendi had to be implemented which would ensure harmony between the Macedonian and Greek immigrants on the one hand and the native population on the other (2001:25).

This became an intractable problem exactly at the time when the dissolution of the colonies of the Egyptian empire started. There always were two nations: the one privileged, the other deprived; the one exploitative, the other exploited. For the first century or more of Ptolemaic rule, the former group consisted entirely of expatriate Greeks and Macedonians who formed 
the elite and upon whom all the riches and spoils obtained from the Egyptian working classes devolved.

The Egyptians had been ruled harshly by the Persians, who also looked down on Egyptian culture and in particular on their religion. Marlow tells us "the Greeks ... showed greater respect and tolerance towards local religions and customs than the Persians had done. The Egyptians therefore preferred them to the Persians" (1971:33). Eddy states, "during the fourth century Hellene and Egyptian had a common interest in defeating the armies of the Persian Great King” (1961:258). Calinescu concurs and says:

The Greeks fought alongside the Egyptians [against the Persians]. It is not surprising therefore that, in the fall of 332 BC, the Egyptians hailed the 24-year-old Alexander the Great and his army of some 40 thousand Macedonians and Greeks as liberators from Persian rule (2004:2).

This euphoria did not last long. Soon, and certainly by the end of the third century BC, Egyptian resentment against the arrogant new rulers became evident. It would seem that imperialist rule, by its very nature, is oppressive.

\section{The response of the Egyptians}

Before Cleopatra VII, no Macedonian of note and very few Greeks ever bothered to learn Egyptian. "This indifference of all Ptolemies before Cleopatra VII to the Egyptian language, let alone to what was written in it, testifies eloquently to a persistent, deep-rooted, allpervasive, cultural separatism in the upper echelons of Ptolemaic society” (Green 1990:326).

Those Egyptians who could read and write Greek were indispensable to the rulers. Hence, these bilingual Egyptians became a crucial factor in the administration. According to Samuel (1993:210), they were the indispensable intermediaries between the Ptolemaic government and the bulk of the Egyptian population.

Imperialist/colonial situations such as that in Ptolemaic Egypt provide opportunities for such men to accumulate greater wealth and influence than would be the case under native regimes, because it is only through their agency that government business can be done. The role of these collaborators was extremely important. Although they formed only about $2.5 \%$ of the total population, it was a very important percentage.

In modern empires, many so-called collaborators also did extremely well for themselves. In the case of the British Empire, this group consisted largely of the former ruling elite and Cannadine points out that they were well rewarded for their services. He states that, “. . . these 'model' princes and sovereigns of empire were amply rewarded and abundantly honoured in ways that deliberately paralleled the treatment of the most decorated British proconsuls” (2001:96).

There can be no doubt that the Egyptians resented the oppression they suffered at the hands of the Greeks. A poignant example of their acute humiliation is to be found in a letter of complaint to Zenon from a non-Greek (c.255 BC):

But they have treated me with contempt because I am a barbarian. I therefore request you, if you please, to order them to let me have what is owed to me / and in future to pay me regularly, so that I do not die of hunger because I do not know how to speak Greek (Verso) to Zenon. P. Col 66 (Austin 1981:418).

The lot of the working Egyptian was harsh indeed. These workers were seen simply as a source of revenue. No wonder that their initial approval of the Ptolemies was dissipated as 
time progressed. Although very little is known of the general Egyptian population until the end of the third century, the mass of labouring Egyptians during the third and second centuries BC were "the more or less obedient servants of their self-assured and prospering Greek masters” (Marlowe 1971:123).

\section{The role of the Macedonians and Greeks}

When we turn to the Greeks, the picture is very different. In Alexandria, a large Greek population was soon resident in the best quarters of the city. They were largely exempt from taxation. There were a number of lucrative opportunities for them: in trade, in government service and in the armed forces, and there was plenty of skilled employment. It is estimated that there were some 150000 adult Greek males in Egypt by the end of the $3^{\text {rd }}$ century BC (Marlowe 1971:44).

Who were these Graeco-Macedonians who settled in the city established by Alexander and who regarded themselves as the masters of the native population? Were they indeed the carriers of Hellenistic culture?

On the contrary, they were soldiers and merchants, not always from the highest cultural background. Green succinctly describes their motivation for settling in Egypt: "The main, indeed the overwhelming motivation that confronts us in these Greek or Macedonian torchbearers of Western culture ... is the irresistible twin lure of power and wealth, with sex trailing along a poor third and cultural enlightenment virtually nowhere” (1990:326). Walbank refers to them as "agents of colonization" consisting mostly of mercenaries left behind by Alexander to hold strategic points. "Once in their new homes these Greeks and Macedonians sank their many differences to become the new master race” (1981:59).

The Greek-speaking population of Alexandria, however, had a second component: the statusless Greek and Greek-speaking permanent settlers, many of whom had fled poverty in the poorer regions of Greece (Fraser 1972:59). Although numerically the largest single element in the city, these Greeks and Macedonians played an insignificant role in the administration of the Egyptian empire. They were for the most part excluded from the intellectual life of the city and they seem to have had virtually no status in the city. These descriptions could be applied to most empires. What motivates imperialists is greed, not idealism.

The Greek immigrants who retained their civic links (apparently indefinitely) to the cities from whence they came, were a small minority, but extremely influential. Representing the main intellectual and administrative class, many of them were in fact invited to Alexandria on the strength of their reputations - particularly those who became attached to the Museum or the Library. Fraser reports that, with very few exceptions, all the great names in scholarship, literature and science were immigrants to Alexandria in the $3^{\text {rd }}$ century (1972:52). These Greek immigrants preferred to remain unassimilated. They regarded their position as Greek émigrés as a status symbol and they were often known by their city of origin - this was particularly true of the artists, scientists and philosophers who were brought to Alexandria by the Ptolemies. This is again typical of the imperialist mentality: the "home" country and one's affiliations with it ensure a status level to which the local citizens cannot aspire.

These people never became Alexandrian citizens; they were foreign residents ( $\xi \varepsilon v o \imath)$, merchants, men of letters, administrators, and soldiers. It seems likely that the very fact that a 
person could claim a connection with the revered Greek homeland was a prerequisite for inclusion in the dominant elite.

The King's "Friends" were drawn from their ranks and at least for the first 100 years of Ptolemaic rule they were regarded as the true elite of the Greek population. The King's council, which operated continuously, though informally, and the army commands, offices of state and ambassadorships were all entrusted to men of the King's choice, his "Friends" (Walbank 1981:75).

Under the early Ptolemies, the expatriate Greeks therefore formed an imperial, privileged elite. As a result of their mercantile astuteness, and the privileges and immunities they enjoyed, many of them acquired considerable wealth. In public life, these Greeks and Macedonians formed the ruling class.

For approximately the first century of Ptolemaic rule the army, like the higher echelons of the civil service, was entirely Greek. The royal person was guarded by a small, handpicked guard of Macedonians quartered in barracks separating the palace from the rest of the city. They seem to have remained Macedonian to the end of the dynasty.

As in most empires, the Greek King's role in Ptolemaic Egypt was a central one. Royal pageantry, largesse and symbolism were always part of the mix. Loyalty to the King was a prerequisite and the fact that the King, by the time of the second Ptolemy, could claim divine status, made his position even more secure. The Ptolemaic court remained entirely Greek, or rather Macedonian, at least during the reign of the first four Ptolemies, as the Vice-regal Court in India centuries later remained entirely British (Marlowe 1971:108).

\section{The social organization of Ptolemaic Egypt: the structures and institutions of Empire}

Arnott (1972:218) points out that the Ptolemaic dynasty attempted to amalgamate Hellenistic ideas with centuries of Egyptian tradition. This was particularly true of the political organization of the state, where the Pharaonic nomes were retained, at least during the initial stages of Ptolemaic rule. In religious matters, the blending of the Hellenistic and the Egyptian traditions reached its apogee in the creation of the syncretic god Sarapis. Philadelphus and his successors also incorporated the morals of their adopted country by marrying their own sisters.

Deep down, however, the Greeks of Alexandria never truly desired integration with the Egyptian population, and did everything in their power to maintain their separate identity, language and culture - particularly in the social arena. Like all imperialists, they regarded themselves as the chosen people, destined to rule over their lesser subjects.

The question arises as to how the Greeks managed to maintain their separate identity and their cultural superiority for so long - at least for the first 100 years, but to a certain degree for the entire 300-year period. This was largely achieved by the importation and maintenance of fundamentally Greek institutions and associations. Such institutions were essential for the maintenance of imperial control, as they demarcated the differences between conquerors and conquered.

Green maintains that the Successors set up what he calls "enclaves of Graeco-Macedonian culture in an alien world, governmental ghettos for a ruling elite” (1990:319). He regards the Greek temples, Greek theatres, Greek gymnasia, Greek mosaics, and Greek-language inscriptions scattered throughout the oikoumene as having been created and maintained for the benefit of the Hellenized Macedonian ruling minority and its Greek supporters. In Egypt, 
specifically, the gymnasion came to resemble an exclusive club, very much like the British clubs of the $19^{\text {th }}$ and $20^{\text {th }}$ centuries in India and other far-flung parts of the British Empire. Similarly, it was only at the very end of Ptolemaic, and British, rule respectively that wealthy local citizens were sometimes admitted to these institutions.

Walbank adds that there were other institutions apart from the gymnasion that also played a significant role in the preservation of Greek culture on foreign soil. These associations were normally informal and consisted of groups of men. They were known as "eranoi, thiasoi, and also by special names, such as Poseidoniastai, linking them with some particular deity worshipped as the patron of the association” (1981:64). Another typical Greek institution, which corresponds more to our modern idea of a gymnasium, was the Palaestra.

Institutions of empire, exclusively for the use of the ruling elite, have occurred in all imperialist/colonialist situations. If the conquerors are not able to distinguish themselves from the conquered, they lose their exclusivity — an essential ingredient of imperialist superiority and control.

\section{Control and exploitation through the economy}

Successful control of the economy is always the first priority of an imperialist power, and the imperialist nature of Ptolemaic rule is most clearly evident in their economic exploitation (more accurately, the rape) of the conquered land and its peoples. This systematic exploitation was carefully managed. One could go as far as to say that it represented the focus of the regime. The whole purpose behind the management of the economy was to maximize the wealth flowing into the Ptolemies' coffers (Walbank 1981:105). Marlowe believes that the success of Soter's policies and the future prosperity of Alexandria were based entirely on his exploitation of the economy: "He and his successors set out to exploit Egypt's natural wealth and the advantages of Alexandria's geographic position to enrich their State Treasury" (Marlowe 1971:39).

The Ptolemaic state was organized along typically imperialist lines. Ruled and administered by the conquerors and assisted by the collaborators, the task was clear: to run the affairs of state in the most efficient manner, ensuring maximum income for the state with the least possible resistance and civil unrest.

Ptolemy I and his successors found themselves forced to devise practicable methods of achieving their main aim, which was to continue collecting rent and tax revenues over a very extensive tract of land from a large number of people whose language they did not understand and who functioned in a different social and economic system from that to which the Greeks were accustomed (Samuel 1993:174). This they achieved by putting several new measures into place to ensure an increased flow of funds into state coffers. New taxes and rents were added in order to cover every possible source of revenue (Walbank 1981:107). Botsford states that it would be impossible to list all of the many taxes (over 200 new ones), "but it is clear that Ptolemy reaped a profit almost every time a man moved in Egypt" (1969:419).

The Ptolemies introduced their subtle and exploitative system of collecting revenue through so-called tax farmers. This iniquitous practice of tax farming was usually reserved for the "Friends of the King" or other rich expatriates, who made exorbitant profits by bidding and paying for the privilege to "farm" a defined area for taxes. In the process, the local population was fleeced. From time to time, however, the Ptolemies included local 
notables as farmers of revenue, since the native aristocracy was co-opted in this way and obtained a stake in the Ptolemaic domination (Bickerman 1970:56). This, of course, is a typical imperialist device, used to lessen feelings of alienation (and thus the possibility of revolt) on the part of the native population.

In addition to the multiplicity of taxes, the Ptolemies imposed an exorbitant system of customs dues and protective tariffs. They also leveled a stunning 24\% interest on loans and, combined with restrictive currency laws, these short-term measures curtailed trade severely (Green 1990:366). Fraser (1972:150) argues that the tariff rates and customs dues, with which the Ptolemies protected home industries, and particularly the Crown monopolies, formed the international counterpart of the monopolistic system of internal trade. Such taxes inevitably were damaging to exports and their application shows how a shortsighted policy aimed at immediate profit to the state dominated all aspects of trade.

Another way of maximizing profit was through the creation of state monopolies such as mines, quarries and salt-works. In those branches of the economy where they did not create out and out monopolies, the Ptolemies introduced strict control that fell short of complete monopoly, but still ensured de facto state control (Walbank 1981:110-111).

\section{Conclusion}

To what extent was Ptolemaic Alexandria under the first three Ptolemies an imperialistic regime? According to any definition of "empire”, Ptolemaic rule in Egypt under the first three Ptolemies must be described as "imperialist". Foreign Kings and their foreign "Friends" ruled the country. There was large-scale exploitation of the indigenous Egyptian population by the Graeco-Macedonians for their own gain. During this time the social stratification of the population, and subsequent segregation of the two races, was still virtually complete. The Graeco-Macedonians did not regard the Egyptians as equals. As in modern empires, the indigenous people were regarded as second-class citizens in their own country, while a group of foreigners held all the prestigious and rewarding positions. This indeed is the hallmark of imperialism. Ptolemaic Egypt complied in every respect.

\section{BIBLIOGRAPHY}

Arnott, P D 1972. An Introduction to the Greek World. London: Sphere Books.

Austin, M M 1981. The Hellenistic World from Alexander to the Roman Conquest: A selection of ancient sources in translation. Cambridge: Cambridge University Press.

Bagnall, R S 1997. Decolonizing Ptolemaic Egypt. In Cartledge, P, Garnsey, P \& Gruen, E (eds), Hellenistic Constructs: Essays in Culture, History and Historiography, 225-241. Berkeley: University of California Press.

Bickerman, E 1970. From Ezra to the last of the Maccabees: Foundations of Post-Biblical Judaism. New York: Shocken Books.

Botsford, G W \& Robinson, C A jr 1969. Hellenic History. London: Macmillan.

Bullock, A \& Trombley, S 1999. The New Fontana Dictionary of Modern Thought. London: HarperCollins.

Calinescu, A 2004. Egypt after Alexander. Bloomington: Indiana University Art Museum.

Cannadine, D 2002. Ornamentalism: How the British saw their Empire. Oxford: Oxford University Press.

Cartledge, P 1993. The Greeks: A Portrait of Self and Others. Oxford: Oxford University Press.

Chua, A 2003. World on Fire. New York: Heinemann.

Cook, C (ed.) 1981. Pears Cyclopedia. London: Pelham Books. 
Eddy, S K 1961. The King is Dead: Studies in the Near Eastern Resistance to Hellenism 334-31 BC. Nebraska: University of Nebraska Press.

Ferguson, N 2004. Colossus. New York: The Penguin Press.

Forest, G 2001. Greece: The History of the Archaic Period. In Boardman, J, Griffen, J \& Murray, O (eds), The Oxford Illustrated History of Greece and the Hellenistic World, 13-43. Oxford: Oxford University Press.

Fraser, P M 1972. Ptolemaic Alexandria. Oxford: Clarendon Press.

Green, P 1990. Alexander to Actium: The historical evolution of the Hellenistic Age. Berkeley: University of California Press.

Hölbl, G 2001. A History of the Ptolemaic Empire (translated by T. Saavedra). London: Routledge.

Kakutani, M 2003. The Rise and Demise of the British World Order and the Lessons of Global Power: review of Ferguson, N, International Herald Tribune 30 April:18.

Kiernan, V G 1974. Marxism and Imperialism. London: Edward Arnold.

Lipset, S M (ed.) 1995. The Encyclopedia of Democracy. London: Routledge.

Lüthy, H 1964. Colonization and the Making of Mankind. In Nadel, G \& Curtis, P (eds), Imperialism and Colonialism, 26-37. Toronto: Macmillan.

Marlowe, J 1971. The Golden Age of Alexandria: From the Foundation by Alexander the Great in 331BC to its Capture by the Arabs in 642 AD. London: Victor Gollancz.

Nadel, G H \& Curtis, P (eds) 1964. Imperialism and Colonialism. Toronto: Macmillan.

Scholtz, L 2003. Interview on 28 November.

Samuel, A E 1993. The Ptolemies and the Ideology of Kingship. In Green, P (ed.), Hellenistic History and Culture, 168-210. Berkeley: University of California Press.

Walbank, F W 1981. The Hellenistic World. Sussex: The Harvester Press.

Woolf, G 2001. Inventing Empire in Ancient Rome. In Alcock, S E, D’Altroy, T N \& Sinopoli, C M (eds), Empires: Perspectives from Archaeology and History, 311-322. Cambridge: Cambridge University Press. 